\title{
The Design of Expert System Applications for Early Detection of Prostate Disease Using Forward Chaining Method
}

\author{
Neny Rosmawarni ${ }^{1}$, Choo Yun Huoy ${ }^{2}$, Zeratul Izzah binti Mohd Yusoh ${ }^{3}$, Annissa \\ Octaviani $^{4}$ \\ \{neny@istn.ac.id ${ }^{1}$, huoy@utem.edu.my ${ }^{2}$,zeratul@utem.edu.my ${ }^{3}$, annissa181097@gmail.com ${ }^{4}$ \} \\ Universiti Teknikal Malaysia Melaka ${ }^{1,2,3}$, Institut Sains dan Tekonologi Nasional ${ }^{1,4}$
}

\begin{abstract}
The focus of this research is on prostate disease which is one of the most common diseases in men in the world. The prostate is part of the male reproductive system, which includes the penis, prostate, and testicles. If the prostate is too large or has a problem, it can cause health problems. One of the health problems in the prostate is a benign prostate gland disease, also called benign prostatic hyperplasia (BPH) and prostate cancer. This study aims to design application of expert systems for early detection of prostate diseases, so that it can help and facilitate users who want to know information about prostate diseases. The method used using the forward chaining method is based on the Knowledge Base System. The results obtained will be created application design expert system that can detect prostate disease early in the form of prototype in Android application using Java programming language and Firebase database.
\end{abstract}

Keywords: expert system, forward chaining, prostate disease, certainty factor, android, prototype.

\section{Introduction}

The prostate is part of the male reproductive system, which includes the penis, prostate and testicles. The prostate, as the largest accessory gland in men, is located just below the bladder and is on the anterior side of the rectum, the size of a walnut and surrounding the prostatic urethra [1]. The seminal fluid produced by the prostate is rich in the content of the Prostate Specific Antigen (PSA) [2]. Prostate epithelial cells produce PSA, which under normal conditions is low. The prostate gland is a fibromascular organ that functions as a gland located below the urinary vesica, useful for producing semen to give strength to sperm to cross the path of the vagina which tends to be acidic, and surround the urethra in the prostate. In addition to containing glandular tissue, the prostate gland contains a lot of fibrous tissue and muscle tissue [3].

The size of the prostate is normally the size of a walnut seed and will increase with age. If the prostate is too large or has a problem, it can cause health problems. One of the health problems in the prostate is a benign prostate gland disease, also called Benign Prostatic Hyperplasia (BPH) and prostate cancer. $\mathrm{BPH}$ is an enlargement of the prostate gland, which can 
cause narrowing or blockage of the urethral lumen and results in non-smooth release of urine. Prostate cancer occurs when genetic mutations are abnormal, malignant tumours can spread to other parts of the body, especially the bones and lymph nodes in the pelvis. About $95 \%$ of patients are diagnosed with prostate cancer in the age range of 45-89 years (average age 72 years) [4][5].

The disease can cause different symptoms in the patient. For this reason, a method is needed to solve the problem of diagnosis. Solving this problem requires an expert system that can utilize the knowledge, techniques and methodologies from various sources. Expert systems can function as human intelligence can learn and adapt to their environment and make the most appropriate decisions. Various methods have been developed to create expert systems, namely soft computing.

In this study the method used is forward chaining, where this technique is used to trace the solution to the problem, for that sometimes the information obtained is incomplete so that it requires a surefire way to answer uncertainty by using the Certainty Factor method to express expert confidence in expressing statement [6][7].

Therefore, the research aims to make the application of early detection of prostate disease based on the Knowledge Base System (KBS) of the expertise of someone in the medical field who will help provide information to the people in need [8]. There is also a formulation of the problem in this study is How this Detection Application can be used for the diagnosis of prostate disease and this application can help the field of medicine and the user. This study limits the problem into two, namely analysing the diagnosis of prostate disease using KBS and this system application is based on Android, using the Java programming language. The benefits obtained from this study are For doctors, as a tool in diagnosing prostate disease and for the community, it is easy to access the application to find information on the diagnosis of prostate disease.

\section{Methodology}

This research method is made structurally starting with doing a problem analysis, then conducting a literature study by reading many journals and scientific books that relate to the problems that want to be resolved and then proceed to the expert interview stage to ask for known statements and the truth of the data obtained, such as from questionnaires and others, then determine the boundaries of the problem, then obtain a needs analysis, design methods and system design, implement and prototype and test using black box testing, then write reports and research publications.

The research and design methods that will be used and applied in this study are shown in Figure 1. As follows. While for the systematic creation method in this study using a prototype method drawn into the flow as shown in Figure 2 below, where the manufacturing process begins with accumulation and analysis requirements, then constructs the prototyping, then system designing, then continues with the system testing stage, resumes to the system implementation stage, proceed to the systematic evaluation stage, and continue to the last stage, namely prototype evaluation. 


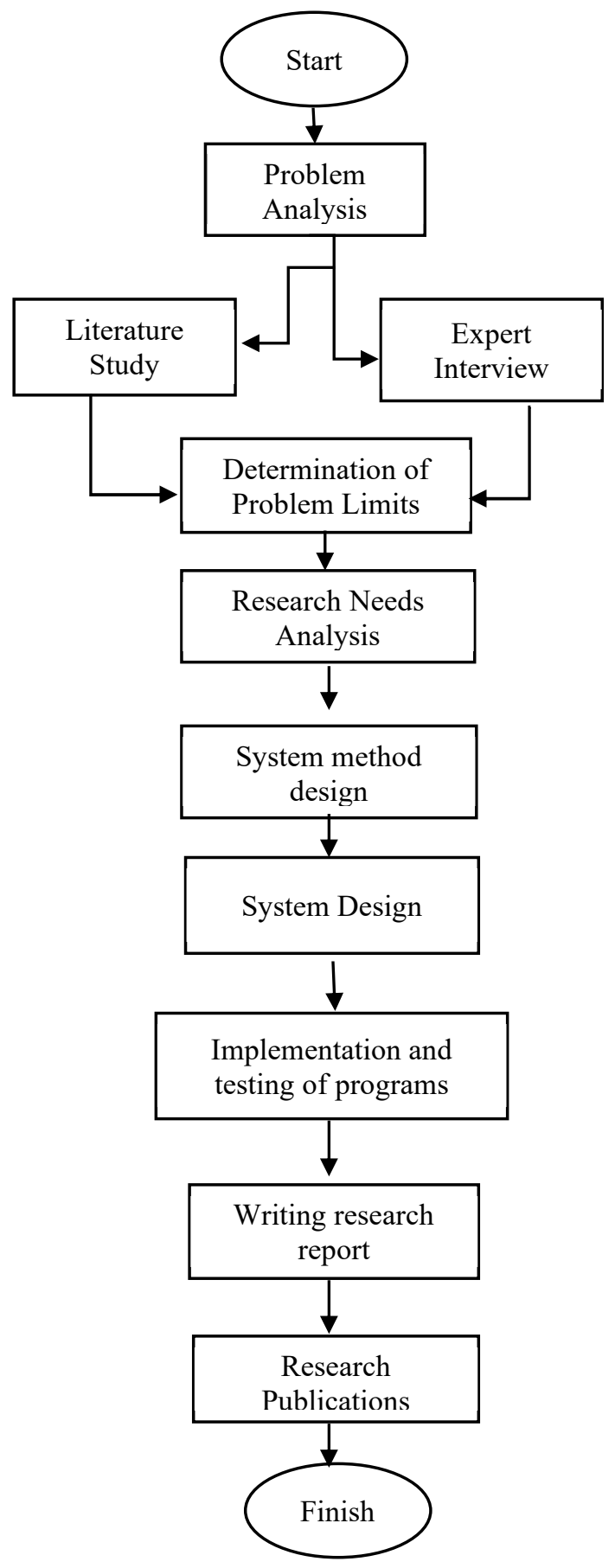

Figure 1. System Design Flow 


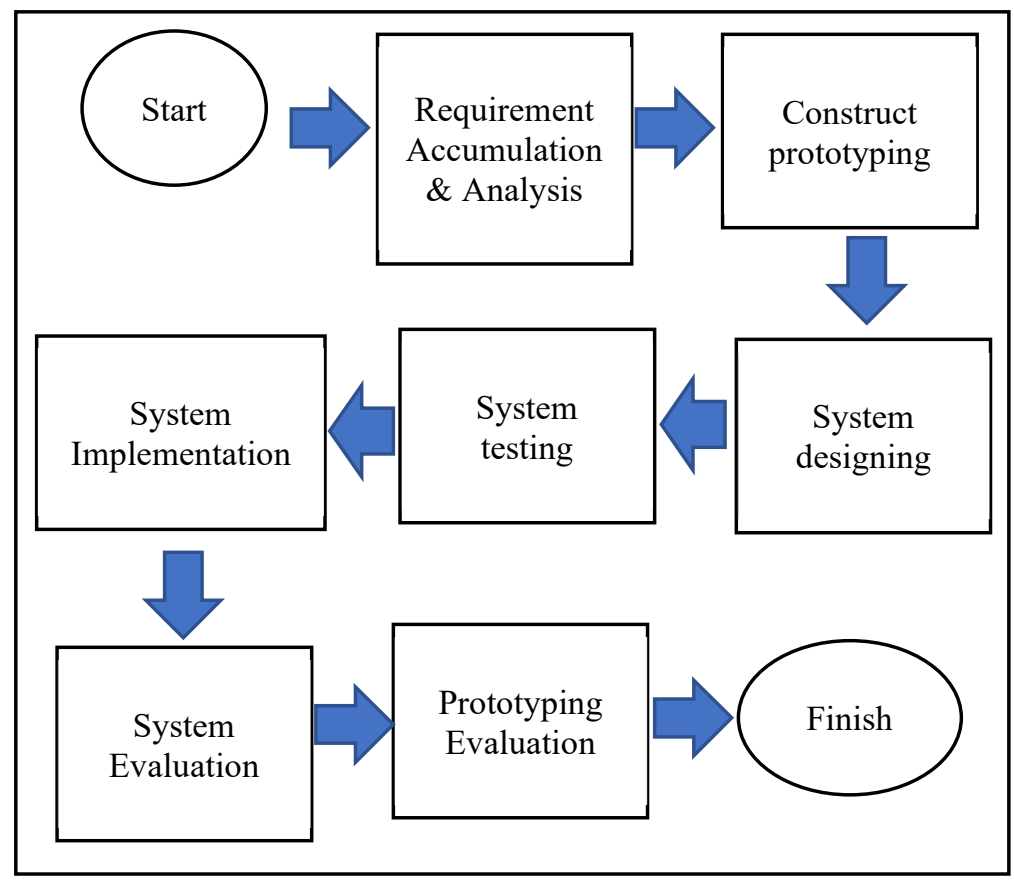

Figure 2. Research Flow 


\subsection{Research Tools and Materials}

a) Hardware: Laptops with specifications: Intel ${ }^{\circledR}$ Core ${ }^{\text {TM }}$ i5-2540M CPU Processor @ 2.60 G. Hz, 2.60 G. Hz Ram, 4 GB, 1TB Hard Drive, Monitor, Mouse and Keyboard, Headset, Mobile Phone with Specifications: Octa-Core Processor Max 1.8 GHz, 3 GB RAM, 32GB Internal Memory.

b) Software Operating System: Windows 10 Pro 64-bit (10.0, Build 10240) \& Android System Version 8.1.0 (Oreo), Java as a programming language, main software: Android Studio.

c) Questionnaire results data, interview results, and results of the literature study.

\subsection{Existing System Analysis}

To analyse the system running as far from the reference that was obtained, investigators, information about prostate disease has been a lot made through the website as a medium to deliver information to the public [9]. But along with the development of technology researchers want to make applications that are easier to use by the public through smart phones. This is because the development of smartphone technology has reached the public at large, and the applications made do not use a lot of internet quota. There are also a number of different research methods in the statements and conclusions of determining disease [10].

\subsection{Proposed System Analysis}

In the analysis proposed this study uses the forward chaining and the Certainty Factor method in the calculation to make statements and conclusions on the determination of prostate disease. An application made using mobile programming on Android using the Java programming language. This application is given the application name "SisPakPros".

The process is described as using a use case diagram, there are two parts, namely the user side of the application and the administrative side that will manage the application and database. Where the admin can manage the content of applications such as managing disease data and application calculations, managing information about hospitals and prostate disease specialists in the application database, managing information about prostate disease in the application, and managing information about the application, which can also update updates. About the application.

This is explained in Figure 3 and for the user side it is also described in the use case diagram as shown in Figure 4 below, where the user can perform early detection by clicking on the disease section to find out the answers to the early detection calculations, then the user can also find information about the hospital which can be a reference for treatment patients, and information about specialist doctors who are competent in the field of this disease, users can also find out information about prostate disease and how to treat it and prevent it, application users can also find information about the application be it information about application updates or others . The following is a use case image diagram admin. 


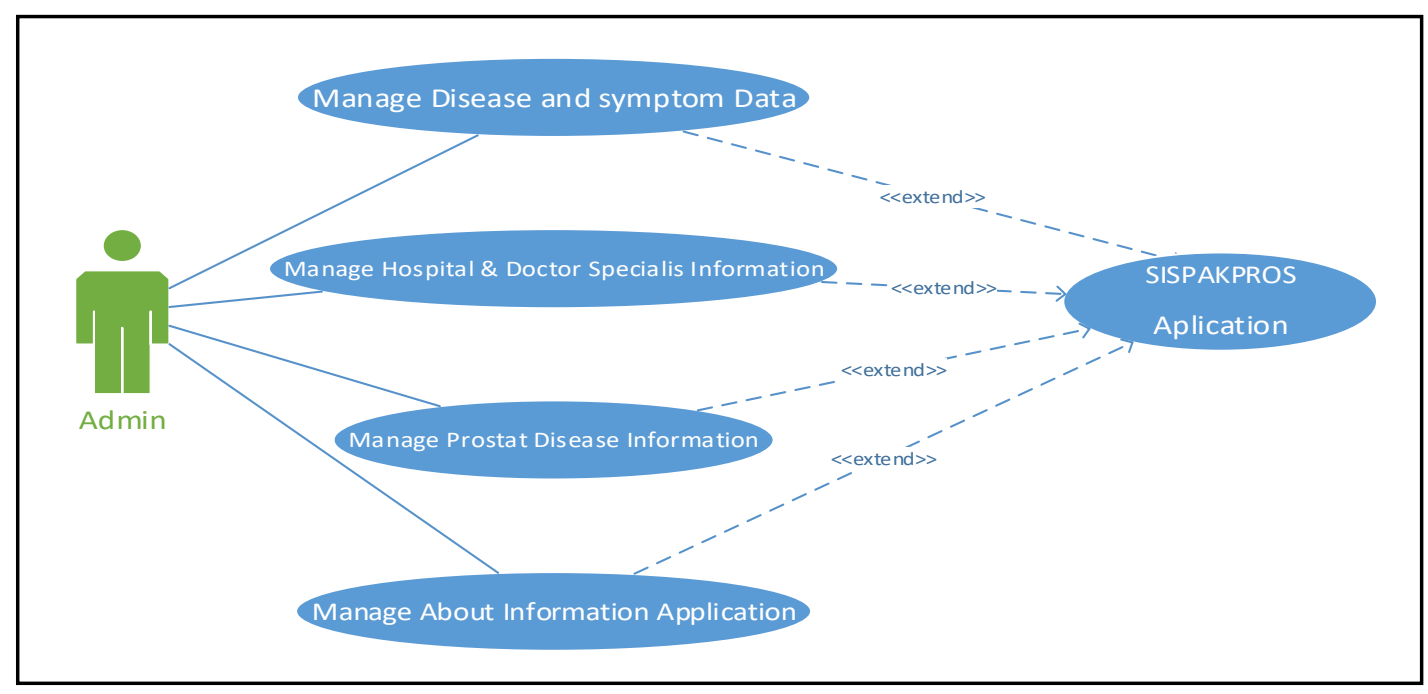

Figure 3 . Use Case Diagram Administrator

Following is the use case diagram of the user user application in picture 4.

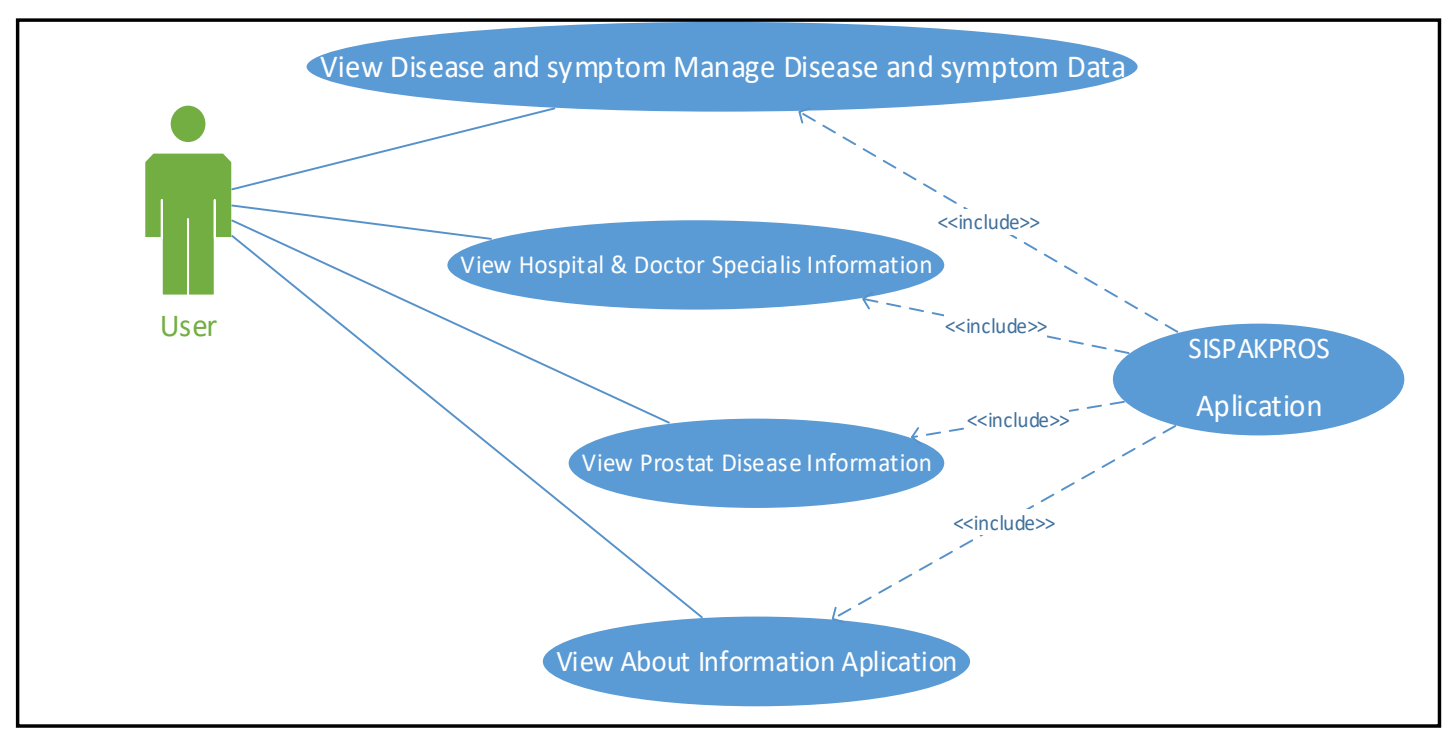

Figure 4. Use Case Diagram User 


\section{Result and Discussion}

In the results section and this discussion discusses what data is collectedandd how the algorithm method is applied in the application. In figure 5 below, is a picture of a table of diseases that are on the male prostate. In this study prostate disease was divided into 3 such as prostatitis, BPH, and prostate cancer. For symptoms of each disease each has 10 symptoms, which if the total number is 30 symptoms. This application is made using this Indonesian language, because the goal is users in Indonesia. So the disease and symptoms in the application are made in Indonesian.

\begin{tabular}{|c|c|c|c|}
\hline No & Penyakit & Gejala & Penyebab \\
\hline \multirow{10}{*}{1} & \multirow{10}{*}{ Prostatitis } & 1. Terjadi di bawah usia 50 tahun & 1. Mengalami infeks saluran kemih \\
\hline & & 2. Geja a berupa flu seperti demam dan meriang (akibat bakteri) & 2. Memiliki riwayat prostattis sebelumnya \\
\hline & & 3. Nyeri pada perut selangkangan dan punggung bagian bawah & 3. Menderita hiv/aids \\
\hline & & 4. Sult menahan BAK & 4. Mengalami cedera daerah panggul dan Iipat paha \\
\hline & & 5. Nyeri/rasa panas saat BAK(dysuaria) & 5. Menggunakan kateter urin \\
\hline & & 6. Unin benvarna keruh & 6. Pernah melakukan biopsi prostat \\
\hline & & 7. Nyer atau rasa tidak nyaman pada penis/testis & \\
\hline & & 8. Nyeri saat ejakulasi & \\
\hline & & 9. Frekuensi BAK meningkat, terutama di ma lam hari & \\
\hline & & 10. Kesultan kencing, sepertivolume air kencing yang sedikit & \\
\hline \multirow{10}{*}{2} & \multirow{10}{*}{$\mathrm{BPH}$} & 1. Bengkak prostat akbat BPH lebih terihat di bagian tenggh & 1. Usia di usia 60 tahun, dan sekitar $50 \%$ di usia 80 tahun \\
\hline & & 2. Tidak bersifat kanker & 2. Seseorang di keluarga memiliki riwayat BPH \\
\hline & & 3. Rata-rata $1 / 3$ usia 60 tahun dan $50 \%$ di usia 80 thenn & 3. Gaya hidup \\
\hline & & 4. Memiliki demam di atas $38^{\circ} \mathrm{C}$, mengggigi, nyeri pada tubuh & 4. Kondisi kesehatan, memilki penyakit diabetes tipe 2 \\
\hline & & 5. Merasa ingin BAK, terutama pada malam hari & 5. penyakitjantung, penyakit peredaran darah \\
\hline & & 6. Kesultan da am mengosongkan kandung kemih & \\
\hline & & 7. Aliran unin yang lemah & \\
\hline & & 8. Memi'iki rasa sakt saat BAK & \\
\hline & & 9. Kesultan da am menampung air kencing & \\
\hline & & 10. Sult untuk memulai atau menghentikan a Iran urin (menetes) & \\
\hline \multirow{10}{*}{3} & \multirow{10}{*}{ KANKER PROSTAT } & 1. Nyeri tuang (punggung, pinggang, paha, atauleher) & 1. Pertambahan usia \\
\hline & & 2. Keleahan dan Penurunan berat badan & 2. Menderita obesitas \\
\hline & & 3. Jumlah sel darah merah rendah (anemia) & 3. Pola makan kurang serat \\
\hline & & 4. Kelemahan atau mati rasa di tungkai atau telapak kaki & 4. Menderita penyakit menular seksual \\
\hline & & 5. Kehilangan kendali BAK atau BAB & 5. Memiikik keluarga yang menderita kanker prostat \\
\hline & & 6. Darah di urin atau hematuria & 6. Paparan bahan kimia \\
\hline & & 7. Aliran urin yang putus-putus & \\
\hline & & 8. Aliran urin yang lemah atau berkurang & \\
\hline & & 9. Rasa sakt saat ejakulasi & \\
\hline & & 10. Rasa terbakar atau nyeri saat BAK & \\
\hline
\end{tabular}

Figure 5. disease data, symptoms and causes

In this study diseases, symptoms, and causes are symbolized as $\mathrm{T}$ for disease, $\mathrm{G}$ for symptoms, and $\mathrm{P}$ for causes. As in the picture table below: 


\begin{tabular}{|l|l|l|r|}
\hline \multicolumn{2}{|c|}{ Simbol } & \multicolumn{1}{c|}{ Jumlah } \\
\hline Penyakit & $=$ & $\mathrm{T}$ & 3 \\
\hline Gejala & $=$ & $\mathrm{G}$ & 30 \\
\hline Penyebab & $=$ & $\mathrm{P}$ & 17 \\
\hline
\end{tabular}

Figure 6. symbol disease

After the data has been obtained and analyzed, then symbolized and made a rule for the results of conclusions and then performed calculations like Figure 7 below, where the first user will enter into the application by answering all the questions asked in the application, then the data is processed with probability calculation then a prediction from the outcome of the jurisdiction will be carried out again with the forward chaining method, then the probability calculation of the patient is suffering from any disease by calculating certainty factors, and then getting a conclusion from the detection whether the user has a disease or normal, if the user has a disease, what disease is treated and how the treatment process and solutions, and prevention.

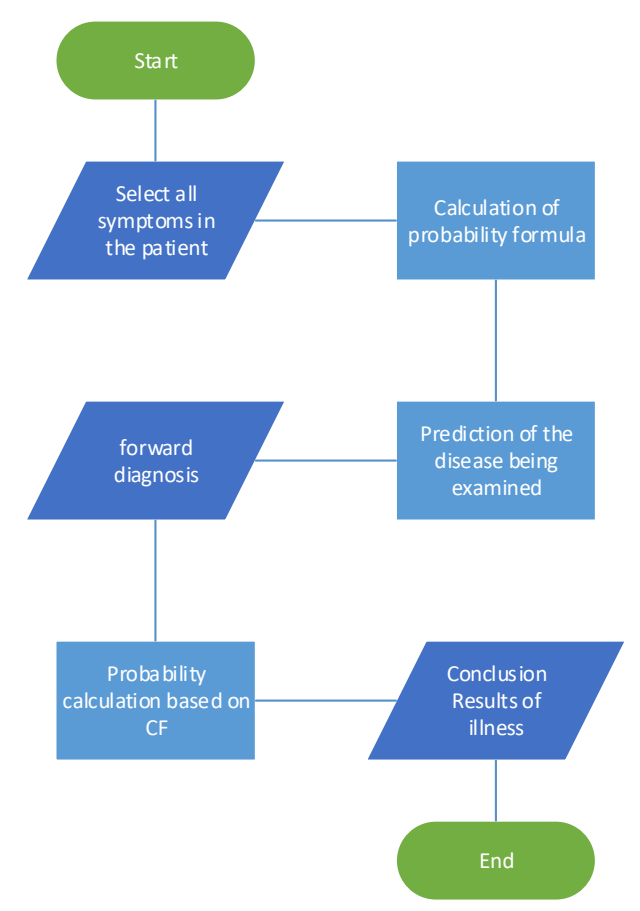

Figure 7. Application calculation algorithm 
In table 1 below is an example of the rule used in the application, and if table 2 is a description of table 1 .

Table 1. Rule Example

\begin{tabular}{|c|c|}
\hline Rule 1 & If $\mathrm{G} 1$ and $\mathrm{P} 1=\mathrm{Ya}$ \\
\hline & If $\mathrm{G} 2$ and $\mathrm{P} 1=\mathrm{Ya}$ \\
\hline & If $\mathrm{G} 3$ and $\mathrm{P} 1=\mathrm{Ya}$ \\
\hline & If $\mathrm{G} 4$ and $\mathrm{P} 1=\mathrm{Ya}$ \\
\hline & If $\mathrm{G} 5$ and $\mathrm{P} 1=\mathrm{Ya}$ \\
\hline & Then T1 \\
\hline \multirow{6}{*}{ Rule 2} & If $\mathrm{G} 11$ and $\mathrm{P} 7=\mathrm{Ya}$ \\
\hline & If $\mathrm{G} 12$ and $\mathrm{P} 7=\mathrm{Ya}$ \\
\hline & If $\mathrm{G} 13$ and $\mathrm{P7}=\mathrm{Ya}$ \\
\hline & If $\mathrm{G} 14$ and $\mathrm{P7}=\mathrm{Ya}$ \\
\hline & If $\mathrm{G} 15$ and $\mathrm{P7}=\mathrm{Ya}$ \\
\hline & Then $\mathrm{T} 2$ \\
\hline \multirow[t]{6}{*}{ Rule 3} & If $\mathrm{G} 21$ and $\mathrm{P} 12=\mathrm{Ya}$ \\
\hline & If $\mathrm{G} 22$ and $\mathrm{P} 12=\mathrm{Ya}$ \\
\hline & If $\mathrm{G} 23$ and $\mathrm{P} 12=\mathrm{Ya}$ \\
\hline & If $\mathrm{G} 24$ and $\mathrm{P} 12=\mathrm{Ya}$ \\
\hline & If $\mathrm{G} 25$ and $\mathrm{P} 12=\mathrm{Ya}$ \\
\hline & Then T3 \\
\hline
\end{tabular}

In table 2 rule information is written in Indonesian because the application is made in Indonesian. In table 2, G1 is the first symptom, for example, if it is under 50 years old or not, while P1 is a cause that can cause disease, T1 is a type of disease and others can be seen in table 2 below:

Table 2. Rule Information

\begin{tabular}{ll}
\hline \multicolumn{1}{c}{ Keterangan } \\
\hline G1 & Terjadi di bawah usia 50 tahun \\
G2 & Gejala berupa flu seperti demam dan meriang (akibat bakteri) \\
G3 & Nyeri pada perut selangkangan dan punggung bagian bawah \\
G4 & Sulit menahan BAK \\
G5 & Nyeri/rasa panas saat BAK(dysuaria) \\
P1 & Mengalami infeksi saluran kemih \\
T1 & Prostatitis \\
G11 & Bengkak prostat akibat BPH lebih terlihat di bagian tengah \\
G12 & Tidak bersifat kanker \\
G13 & Rata-rata $1 / 3$ usia 60 tahun dan $50 \%$ di usia 80 tahun \\
G14 & Memiliki demam di atas $38^{\circ} \mathrm{C}$, menggigil, nyeri pada tubuh \\
G15 & Merasa ingin BAK, terutama pada malam hari
\end{tabular}


P7 Usia di usia 60 tahun, dan sekitar $50 \%$ di usia 80 tahun

T2 BPH

G21 Nyeri tulang (punggung, pinggang, paha, atau leher)

G22 Kelelahan dan Penurunan berat badan

G23 Jumlah sel darah merah rendah (anemia)

G24 Kelemahan atau mati rasa di tungkai atau telapak kaki

G25 Kehilangan kendali BAK atau BAB

P12 Pertambahan usia

T3 KANKER PROSTAT

To explain the menu list in the application, in Figure 8 is a chart of the application menu structure in which there is a splash screen, then enter the main application menu, in the main application, there are 4 menus, namely the Sipakros application is a prediction menu for diseases, then there is a prostate disease information menu, then there is a list menu of hospitals and doctors who can help treat or provide detailed information, then there is a menu of information about the application.

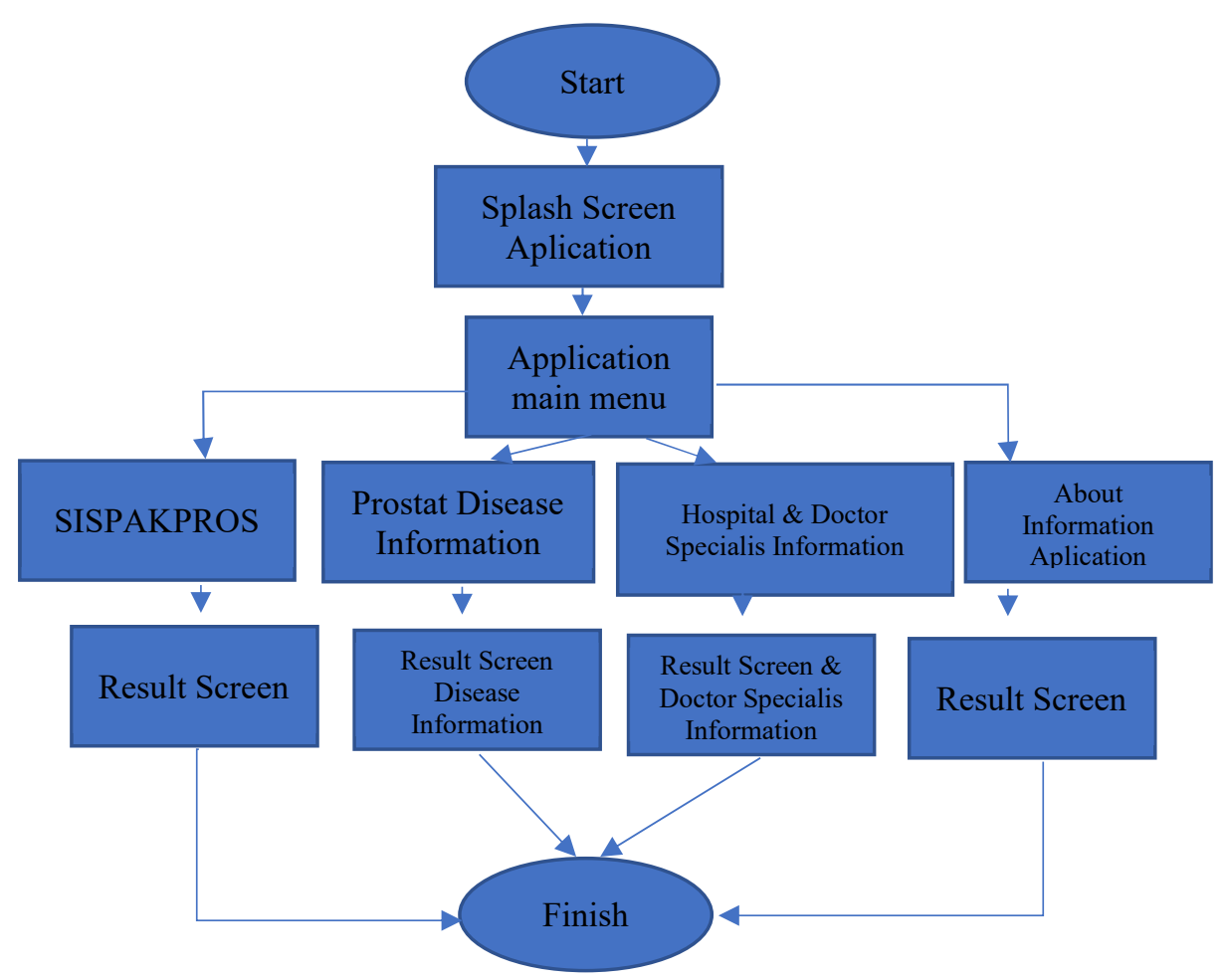

Figure 8. Application Menu 
In figure 9 is an example of a prototype application, as described in figure 8 , in figure 9 this is a display of several user interfaces that can be represented in this paper.
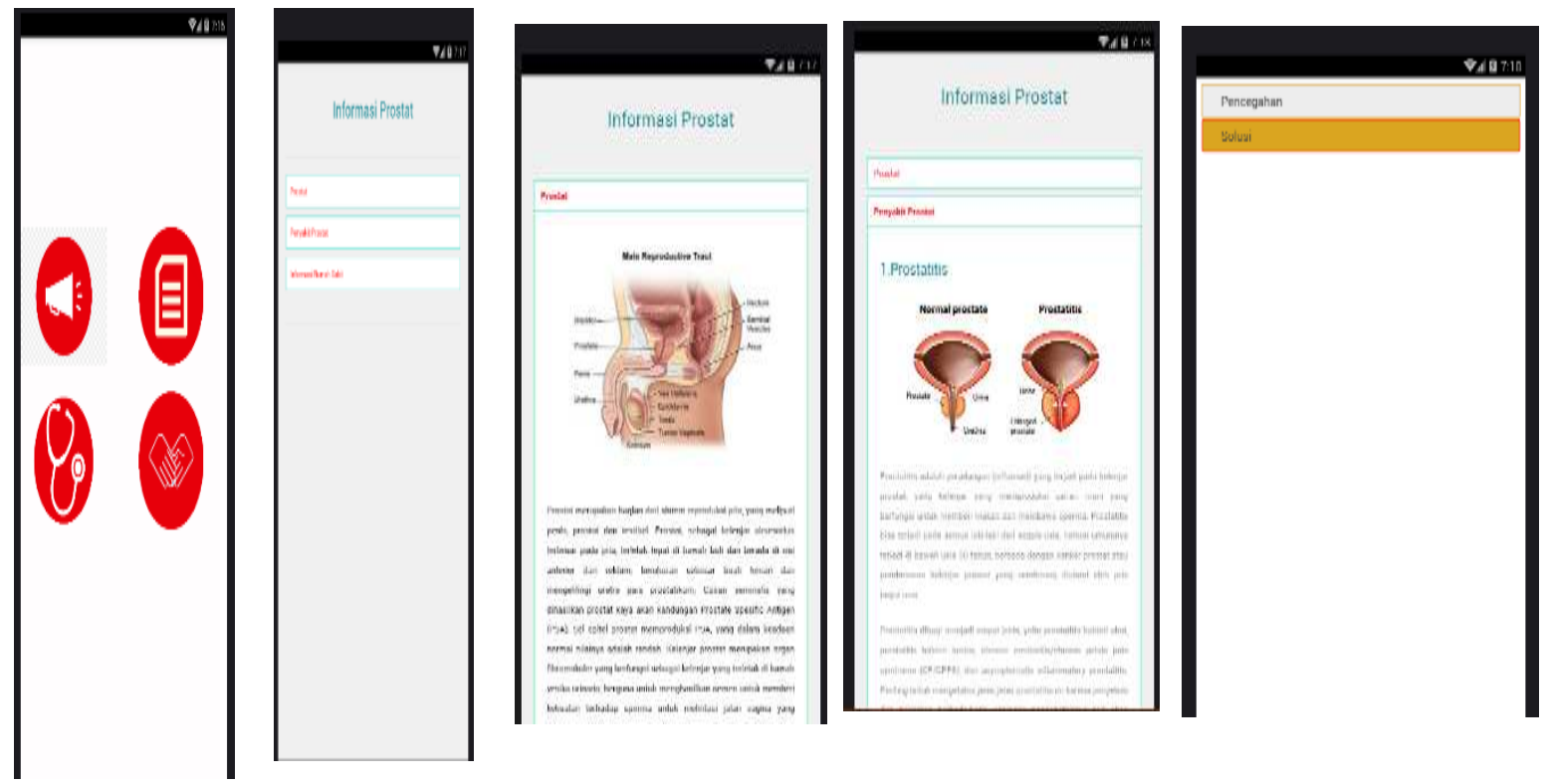

Figure 7. User Interface

\section{Conclusions and recommendations}

\subsection{Conclusions}

In this study a prototype application was named the application "SisPakPros" which serves to help users predict prostate disease (in men) and help make it easier for users to get information about the disease from the way of handling, prevention and information about doctors and hospitals which can help users get more detailed information.

\subsection{Recommendation}

Applications can be developed to be more dynamic and varied and can be developed with other system creation methods and other search methods besides Forward Chaining.

\section{Acknowledgments}

Acknowledgments to LPPM - the Jakarta National Institute of Science and Technology and the Technical Universiti of Melaka Malaysia and to other parties who cannot be mentioned one by one who have supported this Research. 


\section{References}

[1] J. Kangmennaang, P. Mkandawire, and I. Luginaah, "What Prevents Men Aged 40 - 64 Years from Prostate Cancer Screening in Namibia ?," vol. 2016, pp. 14-17, 2016.

[2] C. Bax, G. Taverna, L. Eusebio, G. Guazzoni, and L. C. Id, "Innovative Diagnostic Methods for Early Prostate Cancer Detection through Urine Analysis : A Review," pp. $1-30$.

[3] N. Cernei, Z. Heger, J. Gumulec, O. Zitka, and M. Masarik, "Sarcosine as a Potential Prostate Cancer Biomarker — A Review," pp. 13893-13908, 2013.

[4] A. Monoarfa and F. Tjandra, "Profil penderita kanker prostat di RSUP Prof . Dr . R . D . Kandou Manado,” vol. 4, 2016.

[5] M. A. Tadjuddin Naid, Fitriani Mangerangi, "PENGARUH VOLUME URIN TERHADAP PEMERIKSAAN SEDIMEN URIN PADA PASIEN," vol. 07, no. 01, pp. 1-9, 2015.

[6] G. Abram, F. Suwarso, G. S. Budhi, and L. P. Dewi, "Sistem Pakar untuk Penyakit Anak Menggunakan Metode Forward Chaining."

[7] M. Yunus and S. Setyowibowo, "Aplikasi sistem pendukung keputusan diagnosa penyakit paru- paru dengan metode forward chaining," vol. 2, no. 2, 2001.

[8] J. A. Cruz and D. S. Wishart, "Applications of Machine Learning in Cancer Prediction and Prognosis," pp. 59-77, 2006.

[9] D. T. S. Chang, R. Abouassaly, and N. Lawrentschuk, "Quality of Health Information on the Internet for Prostate Cancer," vol. 2018, 2018.

[10] I. Saritas, N. Allahverdi, and I. U. Sert, “A Fuzzy Expert System Design for Diagnosis of Prostate Cancer," 2003. 